\title{
The occurrence of Crepidobothrium sp. (Cestoda, Proteocephalidae) in Bothrops moojeni (Hoge) (Serpentes, Viperidae)
}

\author{
Reinaldo José da Silva ${ }^{1}$ \\ Andrea Satie Matsubara Karasawa ${ }^{2}$ \\ André Luis Cherubini ${ }^{2}$ \\ Thomaz Henrique Barrella ${ }^{2}$ \\ Carlos Alberto de Magalhães Lopes ${ }^{2}$ \\ Alessandro Francisco Talamini Amarante ${ }^{1}$
}

\begin{abstract}
The occurrence of Crepidobothrium sp. (Cestoda, Proteocephalidae) in the intestine of Bothrops moojeni (Hoge, 1965) (Serpentes, Viperidae) is reported. The host snake was rescued from the fauna in Porto Primavera dam, Mato Grosso do Sul State, Brazil. The snake died in captivity on July 13, 1999. At necropsy, 28 tapeworms were found in the snake intestine. The analysis of specimens morphology allowed the conclusion that they belong to the Crepidobothrium (Monticelli, 1900) genus. It was not possible to determine the Crepidobothrium species due to the lack of the gravid proglottids. This is the first report of $B$. moojeni as a host of cestodes.

KEY WORDS. Cestoda, Proteocephalidae, Crepidobothrium, Bothrops moojeni, snake
\end{abstract}

Snakes are hosts for trematodes, nematodes, and cestodes (MADER 1996). Ophiotaenia (La Rue, 1911), Proteocephalus (Weinland, 1858), and Crepidobothrium (Monticelli, 1900) were the most frequently reported tapeworms in Brazilian snakes (YAMAGUTI 1959)

The Crepidobothrium genus (YAMAGUTI 1959; SCHMIDT 1986; REGO 1995) was characterized by the following: large scolex with vestigial apical organ, four large suckers that are notched at posterior margin (heart- or horseshoe-shape), neck fairly long, distinct external segmentation, testes single layered distributed in two fields, genital pores alternating irregularly, ovary bilobed and posterior, vitellaria in marginal cortex, uterus median and tubular with lateral branches, vagina running anterior or posterior to cirrus pouch.

Taxonomic studies on the Crepidobothrium genus have demonstrated that there are only five valid species that are parasites of snakes: C. gerrardii (Baird, 1860), C. dollfusi (Freze, 1965), C. lachesidis (MacCallum, 1921), C. viperis (Beddard, 1913), and C. garzonii (Chambrier, 1988) (CHAMBrIER 1988, 1989a,b). In addition, it seems that there is a strict specificity between the Crepidobothrium species and the host snakes (CHAMBRIER 1989b).

1) Departamento de Parasitologia, Instituto de Biociências, Universidade Estadual Paulista. 18618-000 Botucatu, São Paulo, Brasil. E-mail: reinaldo@ibb.unesp.br

2) Centro de Estudos de Venenos e Animais Peçonhentos (CEVAP/UNESP). 18618-000 Botucatu, São Paulo, Brasil. 
Species of Crepidobothrium were detected in Bothrops alternatus (Duméril, Bibron et Duméril, 1854), Eunectes murinus (Linnaeus, 1758), and Boa constrictor (Linnaeus, 1758) (CHAMBRIER 1988, 1989a,b). However, there was no report of the presence of Crepidobothrium species or any other tapeworm in Bothrops moojeni (Hoge, 1965). The objective of this paper was to report the occurrence of the Crepidobothrium sp. in a specimen of $B$. moojeni.

\section{MATERIAL AND METHODS}

An adult, male specimen of Bothrops moojeni, rescued in Porto Primavera dam, Mato Grosso do Sul State, Brazil, was donated to The Center for the Study of Venoms and Venomous Animals of São Paulo State University (CEVAP/UNESP). This snake died in captivity on July 13, 1999. At necropsy, 28 tapeworms were found in the snake intestine. These tapeworms were collected and fixed with Railliet \& Henry solution. Fifteen tapeworms were stained with carmine, cleared in creosote, and mounted as permanent preparations in Permount. Morphological evaluation of carmine stained preparations was made using Optimas 4.10 computerized system for image analysis. Two specimens were also examined by scanning electron microscopy (SEM).

\section{RESULTS}

The characteristics and measurements of the tapeworm are $(\mathrm{x}=$ mean): scolex (Figs 1 and 2) large and swollen, wider than the neck, $773 \mu \mathrm{m}$ in diameter and $774 \mu \mathrm{m}$ long, with four proeminent suckers (Fig. 3) opening anteriorly, notched at posterior margin (heart- or horseshoe-shape), with well-marked ropelike edge, $361 \mu \mathrm{m}$ in diameter. Neck present, fairly long, $425 \mu \mathrm{m}$ wide. Strobila acraspedote and polyzoic, $51 \mathrm{~mm}$ long, bearing about 135 proglottids. Intermediate imature proglottids wider than long, $222-305 \mu \mathrm{m}(\mathrm{x}=256 \mu \mathrm{m})$ long and $559-636 \mu \mathrm{m}(\mathrm{x}=600 \mu \mathrm{m})$ wide. Mature proglottids (Fig. 4) longer than wide, 990-1263 $\mu \mathrm{m}(\mathrm{x}=1149 \mu \mathrm{m})$ long and 495-696 $\mu \mathrm{m}(\mathrm{x}=599 \mu \mathrm{m})$ wide. There were no gravid proglottids. Mature proglottids showed single-layered spherical testes, distributed in two fields, 215-233 $(x=223)$ total testis number, divided into 51-59 $(\mathrm{x}=55)$ preporal, 33-50 $(\mathrm{m}=44)$ postporal, and 117-129 $(\mathrm{x}=124)$ antiporal, with $27-34 \mu \mu \mathrm{m}$ long $(\mathrm{x}=29 \mu \mathrm{m})$ and $23-35 \mu \mu \mathrm{m}(\mathrm{x}=28 \mu \mathrm{m})$ wide; cirrus-pouch ellipsoid or piriform, thick-walled, $184-218 \mu \mathrm{m}(\mathrm{x}=203 \mu \mathrm{m})$ long and $72-86 \mu \mathrm{m}(\mathrm{x}=79 \mu \mathrm{m})$ wide; ejaculatory duct long and coiled; vas deferens coiled, occupying round field of $136-188 \mu \mathrm{m}(\mathrm{x}=166 \mu \mathrm{m})$ by $119-153 \mu \mathrm{m}(\mathrm{x}=140 \mu \mathrm{m})$, extending between the proximal part of the cirrus-pouch and the anterior part of the uterus; genital atrium present, well defined, with male and female genital pores, irregularly alternated and situated anteriorly between $28-50 \%(x=41 \%)$ of proglottids length; ovary bilobed, butterfly-shaped and posterior in mature proglottids, each lobe occupying a field of $108-176 \mu \mathrm{m}(\mathrm{x}=145 \mu \mathrm{m})$ by $111-181 \mu \mathrm{m}(\mathrm{x}=150 \mu \mathrm{m})$; vagina running anterior $(70 \%)$ or posterior $(30 \%)$ to cirrus-pouch; uterus distended in the median longitudinal part, 799-1055 $\mu \mathrm{m}(\mathrm{x}=942 \mu \mathrm{m})$ long, occupying $72-90 \%(\mathrm{x}=$ $82 \%$ ) of the mature proglottids length; and vitellaria arranged in two lateral rows, formed by vitelline follicles, $883-1143 \mu \mathrm{m}(\mathrm{x}=1026 \mu \mathrm{m})$ long, extending over $81-95 \%$ $(\mathrm{x}=88 \%)$ length of mature proglottids. 

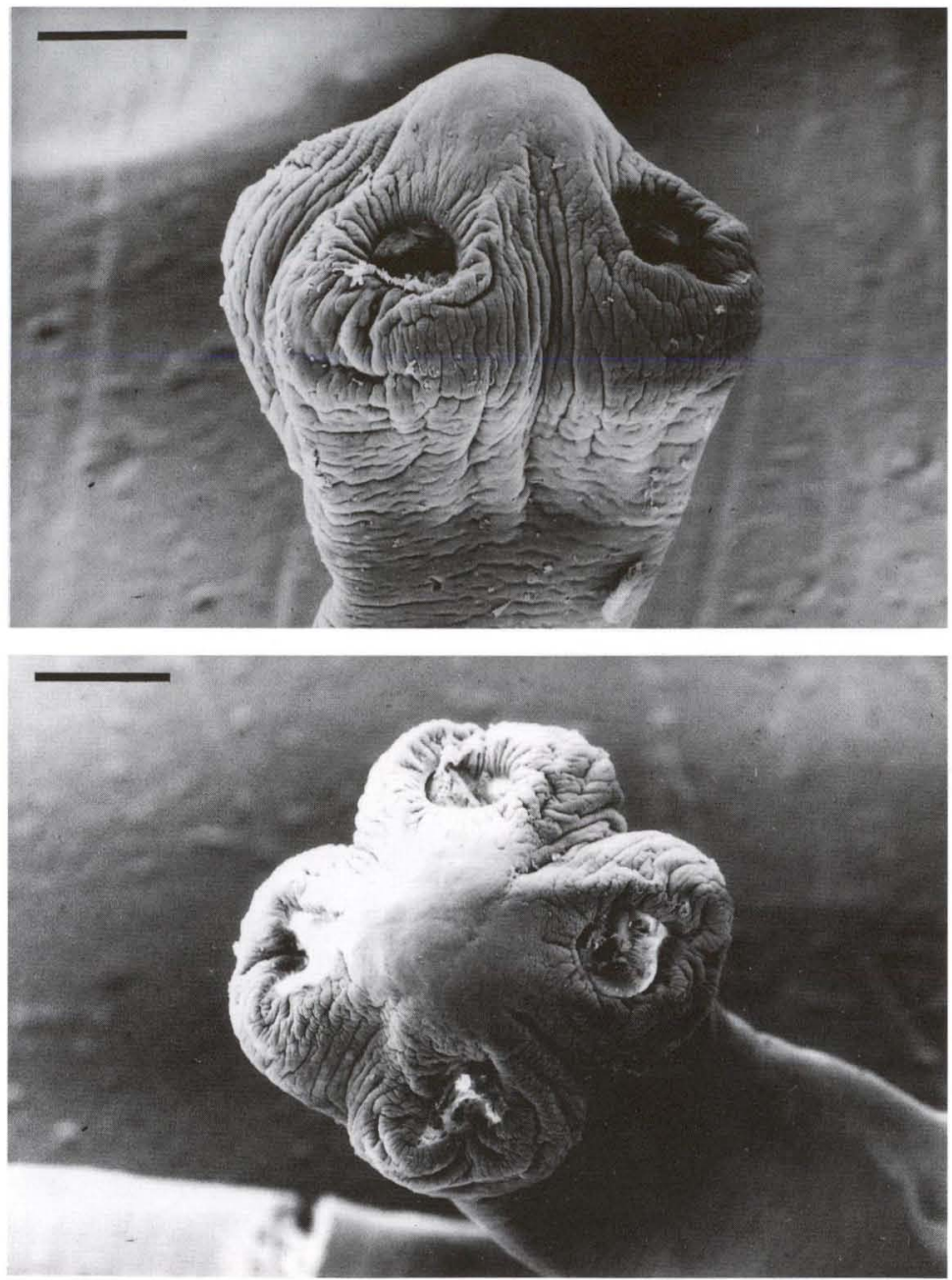

Figs 1-2. Scolex of a Crepidobothrium specimen from a Bothrops moojeni. (1) Lateral view; (2) frontal view. SEM, scale bars $=200 \mu \mathrm{m}$.

\section{DISCUSSION}

This paper describes the first case in literature of the parasite Crepidobothrium sp. infecting a specimen of B. moojeni. In addition, this is the first report of a tapeworm as parasite of this snake species.

For the five valid species of Crepidobothrium genus, only C. garzonii and $C$. viperis were found in $B$. alternatus, a snake closely related to B. moojeni (CHAMBRIER 1988, 1989a). Unfortunately, a complete study for the characterization of this species was not performed due to the lack of gravid proglottis. However, the tapeworm reported in this paper is more resembled to $C$. garzonii than to $C$. viperis. 


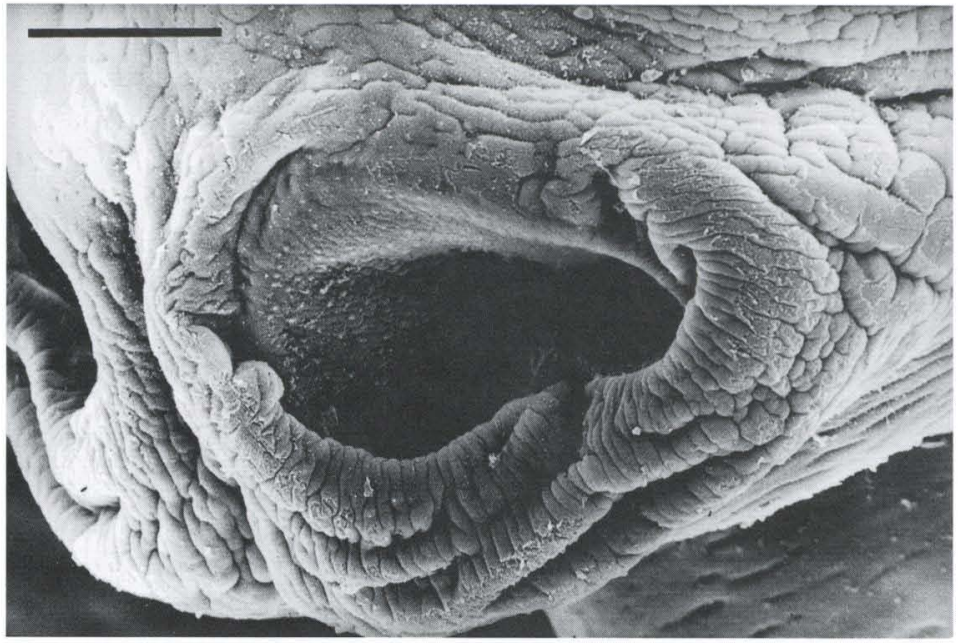

Fig. 3. Detail of the suckers of a Crepidobothrium specimen from a Bothrops moojerm. SEM, scale bars $=100 \mu \mathrm{m}$.

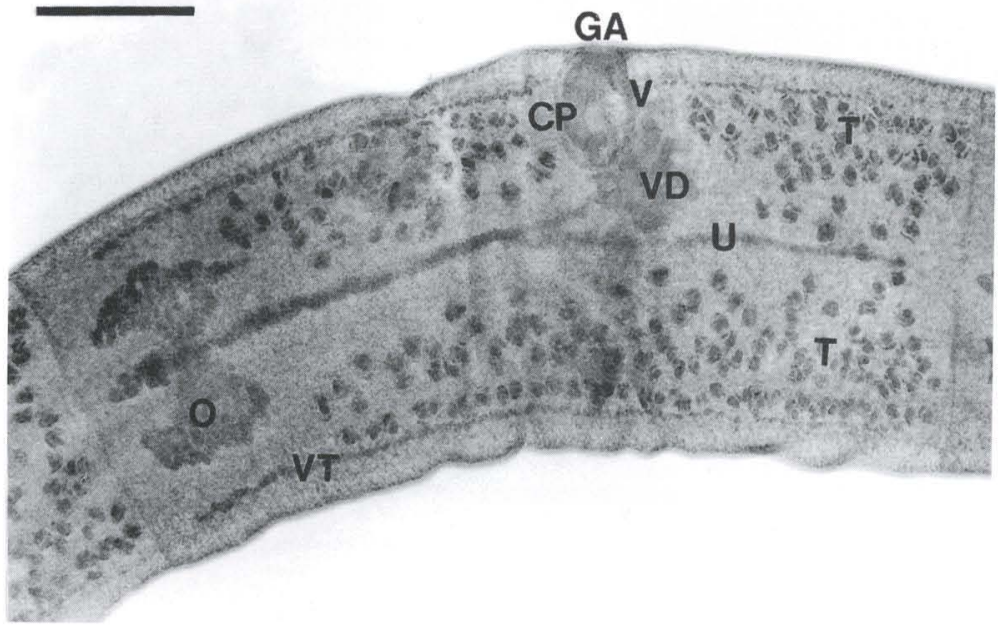

Fig. 4. Mature proglottid of a Crepidobothrium specimen from a Bothrops moojeni. Legend: genital atrium (GA), cirrus-pouch (CP), vagina $(V)$, testes $(T)$, vas deferens $(V D)$, uterus $(U)$, ovary $(\mathrm{O})$, vitellaria (VT). Carmine staining, scale bars $=300 \mu \mathrm{m}$.

The absence of gravid proglottids in this Crepidobothrium sp. may be explained by the fact that the host snake died before the tapeworms were completely developed. Another possible explanation is that the Bothrops moojeni can be an unusual host for this cestode and for this reason its development was not complete. Two species of Crepidobothrium (C. garzonii and C. viperis) were described in Bothrops alternatus, but the cestodes have complete strobila (CHAMBRIER 1988, 1989a). 
CHAMBRIER (1989b) mentioned a possible existence of a strict specificity between the Crepidobothrium species and the host snakes. A snake can be parasitized by one or more species of Crepidobothrium, but one species of Crepidobothrium do not parasitize more than one host. Then, this Crepidobothrium species found in B. moojeni may be a new species. However, the lack of a complete strobila in this tapeworm specimen makes characterization of the new species impossible. Further genetic studies and the search for more cestodes in B. moojeni will be necessary to elucidate this question.

ACKNOWLEDGMENTS. The authors are indebted to N.A. Basso, M.E.L. Peres and M. H. Moreno for their technical assistance, and to H.M.P. Toledo for her assistance with the English review.

\section{REFERENCES}

Chambrier, A. DE. 1988. Crepidobothrium garzonii n. sp. (Cestoda: Proteocephalidae) parasite de Bothrops alternatus Dum. Bibr. \& Dum., 1854 (Serpentes: Viperidae) au Paraguay. Revue Suisse Zool. 95 (4): 1163-1170.

1989a. Révision du genre Crepidobothrium Monticelli, 1900 (Cestoda: Proteocephalidae) parasite d'ophidiens néotropicaux. I. C. gerrardii (Baird, 1860) et C. viperis (Beddard, 1913). Revue Suisse Zool. 96 (1): 191-217.

1989b. Révision du genre Crepidobothrium Monticelli, 1900 (Cestoda: Proteocephalidae) parasite d'ophidiens néotropicaux. II. C. dollfusi Freze, 1965, C. lachesidis (MacCallum, 1921) et conclusions. Revue Suisse Zool. 96 (2): 345-380.

MAder, D.R. 1996. Reptile Medicine and Surgery. Philadelphia, W.B. Saunders, 512p.

REGO, A.A. 1995. A new classification of the cestode order Proteocephalidea Mola. Revta bras. Zool. 12 (4): 791-814.

SCHMIDT, G.D. 1986. Handbook of Tapeworm Identification. Florida, CRC Press, $675 p$.

Yamaguti, S. 1959. Systema Helminthum - The Cestodes of Vertebrates. New York, Interscience Publ., Vol. 2, 860p.

Recebido em 27.IV 2000; aceito em 02.V.2001 